\title{
New Growth for Europe - On Investment, Crisis Management and Growth Potential
}

Growth can be achieved in many different ways, and the diversity in content and approaches within the following articles are testament to that. What they emphasise above all else, however, is that while growth is necessary, the traditional definitions of economic growth are not suitable for the EU in its current state and going forward. What are needed are sustainable, social and inclusive paths toward new forms of growth in Europe.

Imbalances, Inequality and Growth - Rethinking Growth Policies for Europe

László Andor, Corvinus University, Budapest, Hungary; and Hans Böckler Foundation, Dusseldorf, Germany.

The Prospects for Future Economic Growth in the Euro Area

Kieran McQuinn, Economic and Social Research Institute, Dublin, Ireland.

Karl Whelan, University College Dublin, Ireland.

Why Europe Needs a Social Investment Plan

Mario Pianta, Università di Urbino Carlo Bo, Urbino, Italy.

Structural Reforms as a Panacea? The European Productivity and Growth Puzzle

Daniel Gros, Centre for European Policy Studies, Brussels, Belgium.

From Social Pacts to Productivity Boards

Philippe Pochet, European Trade Union Institute, Brussels, Belgium.

After the Brits Have Gone and the Trumpets Have Sounded: Turning a Drama into a Crisis That Will Not Go to Waste

Mark Blyth, Brown University, Providence, RI, USA.

EU Challenges, Investment in the EU and the Role of the European Investment Group

Debora Revoltella, European Investment Bank, Luxembourg.

European Industrial Policy - Tapping the Full Growth Potential of the EU

Erik Berglof, London School of Economics and Political Science, UK.

Making Social Investment Happen for the Eurozone

Anton C. Hemerijck, VU University Amsterdam, Netherlands; and London School of Economics and Political Science, UK.

The Future of European Growth Policies: Resetting Integration

Nauro F. Campos, Brunel University London, UK; and ETH Zurich, Switzerland. 